\title{
A CORRELAÇÃo DE POLÍTICAS PÚBLICAS URBANAS COM O PATRIMÔNIO HISTÓRICO E NATURAL: O CASO DE MANHUMIRIM/MG
}

\begin{abstract}
ANA CAROLINE GUERHARDT LEITE ${ }^{1}$, LIDIANE ESPINDULA ${ }^{2}$.
\end{abstract}
1Graduada em Arquitetura e Urbanismo pelo Centro Univeristário UNIFACIG. carolineguerhardt@hotmail.com.

2 Mestrado no curso de Pós-Graduação em Arquitetura e Urbanismo da Universidade Federal do Espírito Santo (2014). Professora do Centro Univeristário UNIFACIG. espindulaprojetos@ gmail.com.

\section{RESUMO}

As políticas públicas urbanas e patrimoniais desempenham papéis importantes no meio urbano e na história das cidades. A correlação dessas políticas é essencial para a preservação da memória, cultura e o contexto visual da paisagem urbana. $\mathrm{O}$ alinhamento da aplicabilidade dessas diretrizes deve ser parte do processo diário da administração pública e dos usuários do local. O presente artigo tem como objetivo analisar a legislação vigente na cidade de Manhumirim, bem como sua história e patrimônios existentes, com base em pesquisas bibliográficas, levantamento fotográfico e análise do espaço urbano, com foco no centro comercial do município, uma vez que é exatamente onde se localizam obras de maior porte e carga histórica, por se tratar também do local dos primeiros registros da cidade. Mediante o levantamento de dados, é possivel concluir que a cidade possui muita história e memória para ser contada e vivida e, diante disso, seu potencial turístico e econômico poderia ser muito mais valorizado, desde que se fizessem presentes as políticas de planejamento urbano e preservação histórica, cultural e natural. Manhumirim possui um acervo histórico-cultural importante, concluindo assim que a mescla entre espaço urbano e histórico já existe, mas necessita de diretrizes específicas aplicáveis que promovam mudanças no meio urbano patrimonial.

Palavras-chave: Educação Patrimonial; Espaço Urbano; Preservação; Memória.

\section{THE CORRELATION OF URBAN PUBLIC POLICIES WITH HISTORICAL AND NATURAL HERITAGE: THE CASE OF MANHUMIRIM / MG}

\begin{abstract}
Urban and heritage public policies play important roles in the urban environment and in the history of cities. The correlation of these policies is essential for the preservation of memory, culture and the visual context of the urban landscape. Aligning the applicability of these guidelines should be part of the daily process of public
\end{abstract}


administration and site users. This article aims to analyze the current legislation in the city of Manhumirim, as well as its history and existing heritage, based on bibliographic research, photographic survey and analysis of urban space, focusing on the city's commercial center, since it is exactly where are located works of larger size and historical load, because it is also the site of the first records of the city. By collecting data, it is possible to conclude that the city has a lot of history and memory to be told and lived and, in view of this, its tourist and economic potential could be much more valued, provided the urban planning and preservation policies were present historical, cultural and natural. Manhumirim has an important historical-cultural collection, thus concluding that the mix between urban and historical space already exists, but needs specific applicable guidelines that promote changes in the urban heritage.

Keywords: Heritage Education; Urban Space; Preservation; Memory.

\section{INTRODUÇÃO}

O patrimônio histórico e natural de uma cidade compreende os bens materiais e imateriais da sociedade que ali residem, sejam edificações, fotografias, elementos vegetais centenários, entre outros (LEMOS, 2017). A importância da existência desses acervos se dá, principalmente, pela sua carga histórica, carga essa que fica como legado e que deve ser preservada para a posteridade, como um elemento de estudo e contemplação do passado.

Para a preservação desse patrimônio, as políticas públicas são essenciais. Essas são ferramentas governamentais cruciais que coordenam objetivos sociais referentes ao público no geral. Tratando de modo específico sobre diretrizes urbanas, tem-se então diversos fatores de suma valia para o funcionamento ideal de uma cidade (BUCCI, 2013). Correlacionadas ao patrimônio histórico e natural, podem ser destacadas as leis de preservação, acessibilidade, turismo, entre outras, muitas vezes inexistentes em cidades de pequeno porte.

O que é o caso da cidade de Manhumirim, localizada no interior do estado de Minas Gerais, tratando-se de uma cidade pequena com quase 100 anos de emancipação, que cresceu e ainda cresce sem um embasamento legislativo de desenvolvimento urbano eficiente. Observando-se todos os problemas acarretados referentes à aplicabilidade de políticas públicas urbanas, têm-se a precariedade visível em qualquer mínimo espaço do meio urbano, o turismo se faz, na maioria das vezes, esquecido, mesmo a cidade possuindo um acervo - embora não muito grande, mas de elevada expressão - de elementos que remetem a sua história. Esses marcos locais possuem grande relevância na 
história da cidade, principalmente no centro comercial. Há um trajeto da cidade que é contemplado com essas edificações históricas, mas por carência de devidas diretrizes, hoje existe uma desvalorização deste espaço em diversos aspectos urbanos.

Em um contexto atemporal, de acordo com Simmel (2013), um dos grandes problemas encontrados em algumas pequenas cidades é que, culturalmente, as políticas públicas para o bom desenvolvimento, no que tange patrimônio, memória e turismo, são vistas como entrave para muitos dos citadinos e até mesmo para os gestores públicos. Ainda de acordo com o sociólogo, é possível identificar um preconceito existente por grande parte das pessoas, com relação a cultura e a educação nas cidades pequenas, o que acarreta num menor número relativo a turismo nas cidades.

O planejamento urbano requer avaliações para conhecimento de território, sendo assim, o estudo sobre as condições existentes de um determinado município é a premissa básica antes da proposição de diretrizes de planejamento urbano, para que ele seja efetivo de acordo com a realidade vivida no meio urbano estudado (GONZALEZ, 2013 apud STEPHAN, 2017).

Dessa maneira, o objetivo deste estudo é analisar as políticas públicas referentes ao meio urbano e seu impacto no cotidiano do citadino, abordando também as falhas da não aplicação de diretrizes de planejamento adequadas, concentrando-se no espaço histórico-natural da cidade de Manhumirim, com levantamentos de dados sobre marcos, edificações, calçadas e vias, com foco principal no centro comercial, local em que se localizam a via arterial da cidade, bem como a primeira via na qual se fundou a cidade. Fazer um estudo aprofundado sobre a legislação vigente para compreender a relação com a preservação.

\section{MEMÓRIA, IDENTIDADE E EDUCAÇÃO PATRIMONIAL}

Há, desde os primórdios da humanidade, a necessidade cultural da preservação da memória. Sobre isso, Jardim (1995) confirma que, desde a antiguidade, as buscas por salvaguardar as memórias da humanidade já ocorriam por meio da comunicação, das pinturas rupestres, dos códigos, da criação dos alfabetos, cada nação já buscava uma forma de registro para que a história não se perdesse. Esta já é claramente a noção primordial de preservação, que, por sua vez, é importante em diversas escalas, seja 
mundialmente com patrimônios reconhecidos como as sete maravilhas do mundo, que são partes da história edificada, ou mesmo cidades, também em escalas muito menores, como álbuns de família que passam de geração em geração.

Nesse contexto, Lynch (1997) demonstra um grande cuidado e uma grande preocupação com o tempo e a formação da cidade, relacionando os dois com a importância do uso da memória para a adequação harmoniosa do espaço. O urbanista ainda lembra que a imagem ambiental deve possuir identidade, estrutura e significado. Dessa maneira, sabe-se que os patrimônios culturais e históricos de uma cidade possuem exatamente esses três requisitos básicos, dando base a importância da preservação dos acervos históricos e culturais. Concordando com isso, Pereira (2010) enfatiza que é a partir da memória que se constrói e dá-se significado ao cotidiano.

Referente a memória de uma cidade, Tomaz (2010) enfatiza que existe a capacidade de inventar e construir sua história, com base em marcos passados, edifícios históricos, documentos e monumentos, que espaços viram locais com significado, reforçando, então, indubitavelmente, o valor cultural e social da preservação. É importante, portanto, que haja uma gama de legislações específicas, que sejam aplicadas de forma correta com relação à preservação do patrimônio histórico cultural e natural, que é, por definição, parte do legado deixado por várias gerações para a posteridade.

Segundo Le Goff (1990), a memória capacita o homem a atualização do passado e do crescimento intelectual, criando então um vínculo entre as gerações e o tempo. Concordando com isso, Alberti (2004) lembra que o passado permanece vivo nas lembranças emocionais e nos registros científicos da humanidade e o compartilhamento de experiências dá ao indivíduo a base do conhecimento patrimonial, tornando viva a memória da sociedade.

Para Pollak (1992 apud ROCHA, 2012, s/p), “a construção da identidade é um fenômeno que se produz em referência aos outros, em referência aos critérios de aceitabilidade, de admissibilidade, de credibilidade, e que se faz por meio da negociação direta com outros". Complementando, Pelegrini (2006) afirma que a identidade de um local dá-se a partir da memória individual e coletiva que é compartilhada e é por meio desse compartilhamento que há então a criação do ethos (hábito) cultural e da cidadania, que é algo fortemente associado aidentidade. 
No que compete a identidade local, Oliveira (2008 apud ROCHA, 2012) lembra que preservar o patrimônio histórico, cultural e natural de uma cidade, garante a sociedade direito de conhecer sua própria história e de outros que vieram a povoar o espaço que hoje ele ocupa e, por meio dessa materialidade, dessa preservação, que o citadino assegura-se de sua identidade cultural, podendo assim reconstruir o seu passado, garantindo-o as próximas gerações. Dessa maneira, a educação patrimonial se torna ainda mais essencial, uma vez que ela envolve a interação humana desde a fase infantil até a adulta, tendo como base as memórias e a identidade, a troca de experiências entre adultos e crianças, criando o ambiente perfeito no qual se debruça esse tipo de atividade pedagógica.

De acordo com Horta (1999, p.6), a definição para educação patrimonial é puramente "um processo permanente e sistemático de trabalho educacional centrado no Patrimônio Cultural como fonte primária de conhecimento e enriquecimento individual e coletivo" e debruçando-se ainda sobre esse conceito, complementa que:

A partir da experiência e do contato direto com as evidências e manifestações da cultura, em todos os seus múltiplos aspectos, sentidos e significados, o trabalho da Educação Patrimonial busca levar crianças e adultos a um processo ativo de conhecimento, apropriação e valorização de sua herança cultural, capacitando-os para um melhor usufruto destes bens, e propiciando a geração e a produção de novos conhecimentos, num processo contínuo de criação cultural (HORTA, et al, 1999, p. 6).

Concordando com isso, Castro (2006) reforça que a educação patrimonial é uma área pedagógica inicialmente idealizada por Paulo Freire que tem como base, principalmente, o patrimônio cultural. Sua importância se dá por se tratar de um estudo ativo de formação da cidadania e responsabilidade social para com os bens herdados da humanidade, tal educação deve interferir diretamente na vida do citadino, de modo que haja uma maior valorização dos aspectos que caracterizam o local - meio urbano - e a sociedade. Diante disso, é válido salientar que a preservação do patrimônio é fundamental, tanto para guardar as informações, como também os significados, crenças, estética temporal, entre outros adjetivos que competem a um bem patrimonial da sociedade.

\subsection{Das competências de Legislações Patrimoniais e Urbanas}


Entende-se que, para educar, é preciso preservar e, para preservar o patrimônio, é preciso compreender e conscientizar, o que então deve ser feito por meio de legislações que abranjam questões específicas, em escala global, nacional e municipal, começando pelo âmbito nacional (CASTRO, 2006). Canani (2005) sintetiza, de modo claro e objetivo, o âmbito da preservação aos cuidados da legislação nacional, quando afirma que:

\begin{abstract}
A Constituição Federal de 1988 amplia a legislação relativa ao patrimônio cultural, e define as competências de promoção, regulamentação e fiscalização das práticas de preservação, atribuindo um papel mais significativo para o âmbito da administração municipal, e a participação popular nos processos. A participação da comunidade na preservação do patrimônio cultural está prevista em lei para ocorrer de três modos possíveis: na apresentação de projetos de lei, na fiscalização de execução de obras e na proteção do bem, preservando-o (CANANI, 2005, s/p).
\end{abstract}

Com base nisso, sabe-se então que, apesar de ser de competência de administração municipal, a participação popular no processo de preservação é muito importante. Canani (2005) enfatiza que o cidadão possui várias formas de participar diretamente da preservação do patrimônio cultural, seja em conjunto de outros que tenham mesmo interesse ou em conjunto com entidades associadas. Sobre esse contexto de ajuda mútua, Oriá (2013) lembra que todas as pessoas têm direito a memória que o patrimônio carrega, mas também têm o deverde zelar por ela. O que impulsiona esse dever é o conhecimento, pois entender as legislações leva o cidadão a compreender a importância desse exercício, que não somente é uma tarefa, mas um ato decidadania.

O Brasil demorou muito a se preocupar com preservação de patrimônio e história, Canani (2005) afirma que, após a criação do Instituto do Patrimônio Histórico e Artístico Nacional (IPHAN) no ano de 1934, a constituição vigorou a lei de proteção às belezas naturais e históricas do Brasil. Ao final do ano de 1937, foi promulgado um decreto de lei, que regulamentava o tombamento de marcos históricos para a humanidade e que tornava o proprietário responsável pela sua conservação. Entretanto, apenas no ano de 1945 essa prática foi realmente disseminada; com a criação da Unesco, o órgão internacional que regulariza mundialmente a efetividade das legislações e tem como base a promoção da paz e os direitos humanos com a solidariedade intelectual e moral da humanidade, que se dá por meio da preservação da ciência e da história (CANANI, 2005). 
Ainda de acordo com Brasil (1988), o tombamento é a forma eficaz de preservação, instituída pelo Decreto $\mathrm{n}^{\circ} 25$, e é adequada a proteção de bens tangíveis, tais como edificações, paisagens e conjuntos históricos urbanos e intangíveis como festas religiosas e ofícios antigos. Outras formas de preservação são os registros e os inventários, que salvaguardam aos marcos sua permanência e indubitável valor histórico e sociocultural (BRASIL, 1988).

Os bens tombados de natureza material podem ser imóveis como as cidades históricas, sítios arqueológicos e paisagísticos e bens individuais; ou móveis, como coleções arqueológicas, acervos museológicos, documentais, bibliográficos, arquivísticos, videográficos, fotográficos e cinematográficos (IPHAN, 2014, s/p).

Como designado pelo IPHAN, os bens tangíveis tratam não somente, mas também de cidades históricas, sítios arqueológicos e paisagísticos; portanto, dá-se então a importância de correlacionar as políticas públicas urbanas, aliando mais efetivamente o patrimônio histórico com seu entorno, utilizando disso então para criar uma paisagem atrativa ao usuário.

A dissociação do meio urbano com o patrimônio existente em uma comunidade descaracteriza o local e causa um rompimento na paisagem. Mediante isso, Reis (2011, p.117) destaca essa falta de conversação entre as práticas de preservação e as políticas públicas:

Responsáveis pela preservação do patrimônio cultural, consciente ou inconscientemente, interferem diretamente nas diretrizes de planejamento urbano, sem delegação para isso e, reciprocamente, planejadores urbanos passam simbolicamente seus tratores sobre os bens culturais, quando não o fazem em campo, materialmente, igualmente sem atribuição para isso (REIS, 2011, p.117)

Dessa maneira, entende-se então que essas normas devem ser compreendidas e aplicadas como complementares e não como independentes. A partir disso, Funari (2009) ressalta que, mesmo com a dissociação dessas áreas de política pública nos âmbitos urbano e histórico, elas continuam independentemente sendo importantes ferramentas de promoção de cidades no mercado mundial; entretanto, se aliadas, podem ser o mecanismo de fomentação mais eficaz para o crescimento cultural, social e econômico dos sítios históricos. 
Gomes (2011) lembra que o patrimônio histórico e a cultura, de um modo geral, são pontos importantes da cidade contemporânea, são eles que configuram o espaço como peças de um grandioso espetáculo, isso, porém, não significa que as ações dos órgãos públicos voltado ao planejamento urbano se associam com as voltas à preservação do patrimônio. Assim, compreende-se então que há falhas na correlação dessas políticas de planejamento e preservação das cidades.

A eficácia conjunta das diretrizes de preservação e planejamento ainda é insignificante, dado tamanho o benefício que uma cidade pode alcançar correlacionando a sua aplicabilidade. O alinhamento adequado dessas políticas se faz necessário, principalmente, para que as competências de uma não tomem frente às da outra, visto que pode ocorrer uma descaracterização da paisagem histórica, exatamente devido ao uso do urbanismo contemporâneo que é aplicado hoje nas cidades. Nesse caso, um mau alinhamento da aplicação das diretrizes pode ser um enorme problema de perda de identidade cultural de um local e, até mesmo, de caracterização histórica.

Apesar dessa dificuldade, o Brasil possui bons exemplos que aplicados na prática funcionaram além da preservação, aliaram-se a acessibilidade, turismo e economia.

\subsection{Estudos de Caso}

Para fins de questionar o alinhamento das políticas públicas urbanas e patrimoniais, toma-se como fontes de estudo o caso do Pelourinho, em Salvador/BA, por se tratar de uma área de indubitável valor histórico, que atrai olhares do mundo todo, tanto como forma de entretenimento quanto como um patrimônio de grande valor a história nacional. Também toma-se como fonte o caso do Caminho do Ouro, em Paraty/RJ, escolhido por seu valor histórico e natural e por ser um caso de escala menor que o primeiro, de modo que os dois deem a base necessária para a comparação com o patrimônio histórico e natural em potencial da cidade de Manhumirim, no estado de Minas Gerais.

\subsubsection{Pelourinho - a preservação e o direito a cidade}


A região do Pelourinho fica localizada na cidade de Salvador, no estado da Bahia, possui construções do período colonial, marcas da colonização portuguesa em uma das antigas capitais do Brasil (Figura 1). De acordo com Del Rio (2013), a reabilitação dessa área durou cerca de vinte anos, começando no ano de 1992 e ocorrendo até o ano de 2012. Em seu início, a intenção era turística e cultural: resgatar o passado colonial de forma a preservar a arquitetura local, melhorando-a nos aspectos estéticos (Figura 2), com a adição das cores vivas que pintam a paisagem e marcam a sensação de alegria característica do estado da Bahia. Mas não somente a beleza fora valorizada com a reforma, mudanças infraestruturais foram concebidas para o atendimento da demanda turística deste grandioso centro cultural e histórico brasileiro.

Figura 1: Pelourinho, 1859

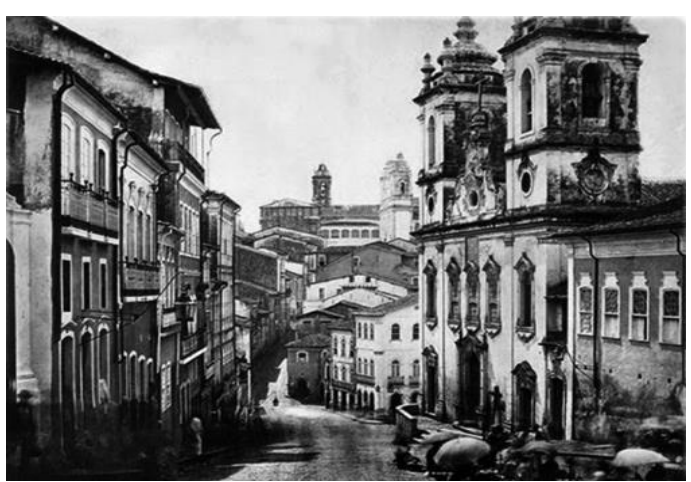

Fonte: Mulock, s/d
Figura 2: Pelourinho no ano de 2015

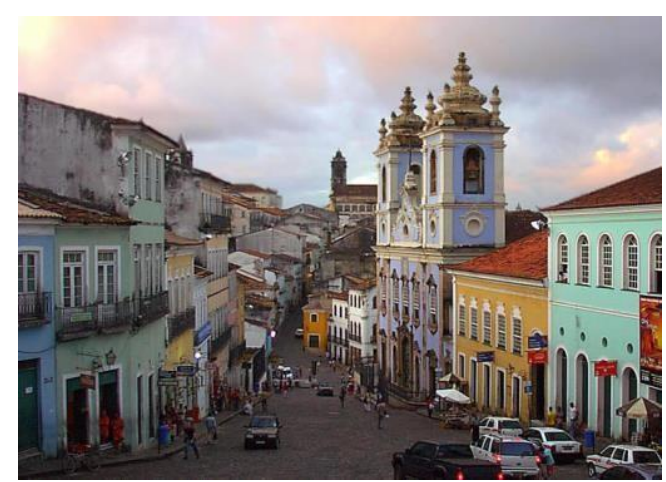

Fonte: Varela, 2015

De acordo com Barreto (2008), há correlação de políticas de turismo e entretenimento com as de preservação; além disso, as políticas públicas se fizeram presentes na melhoria da infraestrutura urbana, quanto a princípios básicos de saneamento e adaptação das vias, como também acessibilidade de pedestres que foram modificações no contexto geral da reabilitação local. O foco principal na repaginação da paisagem, ainda de acordo com o autor, foi no entorno mais convidativo, com uso de fachadas multicoloridas, largos que promovem a interação social e cultural, transformando o entorno histórico em um local convidativo.

No que tange a relocação popular, as famílias que ali moravam ganharam novas moradias totalmente cedidas pela prefeitura da cidade; entretanto, há controvérsias ainda. Barreto (2008 apud RODRIGUES, 1995) enfatiza que as pessoas que ali moravam não se sentem realocadas, e sim descartadas, pois o local ao qual pertenciam fora retirado e 
cedido a grandes empresas que agora comercializam o local, processo conhecido como gentrificação.

Dessa maneira, é notório que a preservação não deve se aliar ao descaso social, pois não existe uma história sem alguém que possa contá-la. A tentativa de resgate cultural não deve passar por cima da cultura viva, que é a própria sociedade local. É de grande importância que sejam dadas condições dignas de saneamento, circulação viária e acessibilidade, que tudo isso se alinhe com o resgate estético e turístico, mas, para implementação de quaisquer desses, não se deve abdicar de experiência humana, pois a memória vivida e contada também é patrimônio cultural e histórico da sociedade.

\subsubsection{Caminho do Ouro - A preservação de Paraty/RJ}

Cidades históricas são pontos turísticos e se essa história vem acompanhada de um belo patrimônio natural, o aumento de visitações a esses locais é naturalmente esperado. Esse é o caso da cidade de Paraty, localizada no estado do Rio de Janeiro, em uma rota conhecida como o Caminho do Ouro, que começa em Diamantina, passando por Ouro Preto, São João Del Rei, Tiradentes, entre outras cidades do estado de Minas Gerais, até chegar na cidade de Paraty. De acordo com Paraty (s/d), é prevista a restauração de $12 \mathrm{~km}$ de extensão deste caminho, entretanto, apenas $4 \mathrm{~km}$ foram reabilitados até hoje.

Visando o turismo, a preservação cultural e a preservação natural, a área do centro histórico, que corresponde a quase todo o trajeto da área principal da cidade, foi reabilitado: não somente as vias que mantém a pavimentação de pedras original, como as edificações do entorno que funcionam, em sua maioria, como locais comerciais e de serviços (Figura 3). A pavimentação tem local de destaque, uma vez que é sempre inundada pela maré, o que se tornou um patrimônio natural do local (PARATY, s/d). 
Figura 3: Via comercial, 2015



Fonte: Débora, 2015.
Figura 4: Avenida tomada por maré, 2015



Fonte: Guri Estradeiro, 2015.

Segundo Paraty (s/d), as melhorias na pavimentação, sem a perda das pedras que originalmente cobrem o trajeto, deram-se devido a inundação da maré, que cobre uma vez por dia parte das vias, funcionando como um agente natural de limpeza. A subida da maré é algo que acontece desde os primórdios da cidade, por se tartar de uma cidade portuária, as edificações são acima do nível da rua, para evitar inundações no interior delas. Por se tratar de algo histórico e natural, a pavimentação foi mantida exatamente para a preservação do acontecimento da cheia da maré, que se tornou parte do turismo em Paraty.

De acordo com Paraty (s/d), também houve um cuidado significativo com a iluminação urbana, uma vez que, em tempos antigos, não havia hábitos noturnos e, contrariamente, hoje há, principalmente por parte de turistas jovens que visitam a região. Com as mudanças positivas ao centro histórico, ocorreu também uma maior oportunidade de empreendimento; aproveitando-se da alta do turismo, o crescimento de novas empresas de pequeno e médio porte, com foco em hospedagem, alimentação e trabalhos manuais que resgatam a cultura local por meio do artesanato, principalmente. Houve também um aumento significativo no transporte público, para melhor atender a área do centro e as demais no restante da cidade.

Bem como a revitalização da grande maioria dos centros históricos que se tem registro, há controvérsias na conclusão do objetivo principal. Os locais se mantêm preservados, tornam-se pontos turísticos. Paraty, por exemplo, também atrai olhares para sua paisagem natural composta por ilhas e praias do entorno; entretanto, a segregação das famílias que antes moravam no centro histórico ocorre como no Pelourinho, o que afasta de maneira indireta parte da memória daquele local (PARATY, s/d). 
Em alguns casos, como cita Campos (2013), ocorre ainda uma gentrificação dessas áreas históricas, pessoas mais abastadas possuem capital suficiente para se manterem morando nesses centros, enquanto outras pessoas são relocadas e, algumas vezes, afastam-se para as periferias, perdendo o privilégio de estar onde realmente há tudo na cidade. É, portanto, muito importante que haja o real alinhamento de políticas públicas urbanas e patrimoniais, sem que se deixe de lado a cidadania e a responsabilidade social para com os usuários, principalmente os citadinos, que carregam a memória e o pertencimento histórico.

\section{METODOLOGIA}

O presente estudo possui pesquisa aplicada que, por meio de levantamento bibliográfico para a construção do referencial teórico, analisou o posicionamento de legislações urbanas e patrimoniais, bem como estudos de caso da aplicabilidade dos planos de políticas públicas.

Manteve-se, então, um paralelo dessas análises com a apresentação de pesquisa documental, contendo informações obtidas in loco na cidade de Manhumirim-MG, constando de estudos da infraestrutura urbana e desenvolvimento histórico e comportamental municipal, aliando a estudos da legislação vigente, levantamento fotográfico e estudos em mapas aéreos com foco, principalmente, na região que compreende o centro comercial da cidade e seu entorno. Iniciando na Rua Alfredo Lima, passando pela Travessa Alex Miranda, seguindo pelas ruas Trajano Lima, Alvimar Tanus e Padre Júlio Maria, com atenção especial as praças principais da cidade, que são a Praça Padre Júlio Maria e a Praça Getúlio Vargas, pontos de interesse comum.

\section{ANÁLISE DE DADOS E DISCUSSÃO}

Com base nos dados do Instituto Brasileiro de Geografia e Estatísticas (IBGE, 2012) e da Associação Comercial de Manhumirim (ACIAMA, s/d), a cidade de Manhumirim está localizada entre as montanhas do leste do estado de Minas Gerais (Figura 5), na região da Zona da Mata Mineira, a pouco mais de trezentos quilômetros da capital Belo Horizonte. A cidade possui uma posição favorável, uma vez que se encontra 
às margens das rodovias estaduais MG-111 e MG-108 e é servida pelas rodovias federais BR-262 e BR-116. Caracterizada por ser uma cidade de pequeno porte, com 21.382 habitantes, segundo o último censo do IBGE no ano de 2010 (IBGE, 2012).

Figura 5: Mapa da cidade de Manhumirim

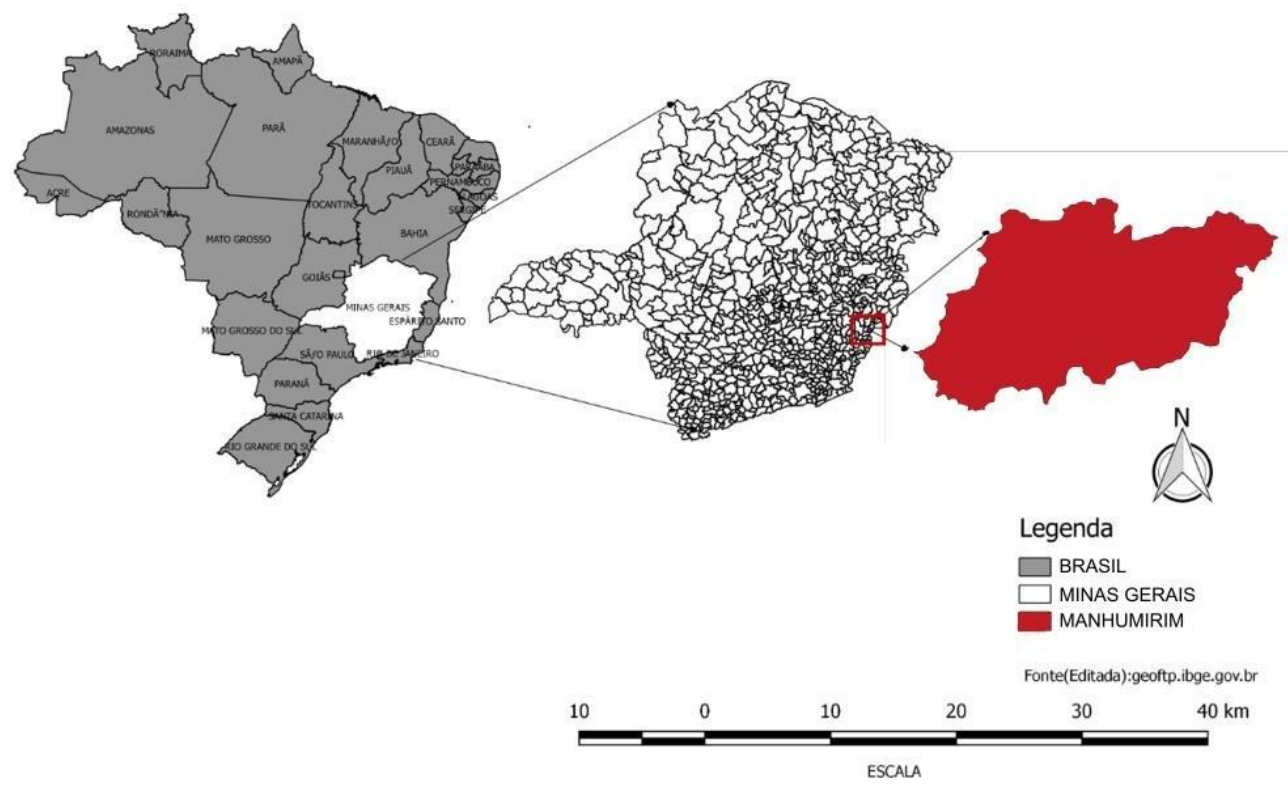

Fonte (editada): IBGE, 2010.

Segundo Botelho (2011), os primeiros registros da cidade datam de 1808, quando D. João VI ordenou a abertura de uma estrada ligando a cidade Vitória, capital do Espírito Santo, a então capital mineira Vila Rica para facilitar o deslocamento por entre matas e serras. Havia, no decorrer dessa estrada, pontos de apoio que serviam de abrigo às diligências que levavam mensagens e suprimentos, esses pontos eram os quartéis e um deles se localizava exatamente onde hoje se encontra a cidade.

A economia local, de acordo com a ACIAMA (s/d) e o IBGE (2012), está baseada na agricultura, com predominância no cultivo de café, como já acontece desde os primeiros registros do início da cidade. No entanto, hoje ainda se divide em pecuária e comércio, mas com aglomeração, principalmente na via principal, que antes abrigava a linha de ferro da rota do café, que desenvolveu o comércio e, consequentemente, atraiu mais moradores para cidade, que com esse impulso começou a crescer.

\subsection{O Centro Histórico de Manhumirim}


Ainda de acordo com Botelho (2011), o primeiro grupo realmente desbravador de terras na região data de 1864, liderados por Manoel Francisco de Paula Cunha, um português desertor da guerra do Paraguai que buscou, então, refúgio em terras ainda não habitadas. Sendo muito religioso, acabou por ceder parte das terras para a construção de uma Igreja em homenagem ao Bom Jesus, com isso, dando o primeiro nome do então distrito de Bom Jesus do Pirapetinga.

O distrito não passava de uma via extensa que, com a chegada da estrada de ferro, ganhou outra via e, a partir da chegada do missionário Pe. Júlio Maria Lombaerde, que logo se tornou o progenitor da evolução religiosa e urbana da cidade, principalmente no centro. Sua obra é indubitavelmente o maior legado da cidade, uma vez que, de sua parte, havia preocupação moral e física com os moradores. Deixados de seu legado temse na cidade: a Igreja Matriz do Bom Jesus, o Seminário Apostólico Romano, o Colégio Santa Terezinha (Mapa 1) e o Hospital da cidade, que, apesar de ser um pouco afastado do centro, é válido ser lembrado (BOTELHO, 2011). É valido lembrar também de uma edificação do centro histórico que chama atenção graças a sua conservação, o Palácio das Águias (Mapa 1), que, apesar de não ser obra do pároco, data da mesma época.

Mapa 1: Mapa de localização dos pontos de interesse do centro da cidade.

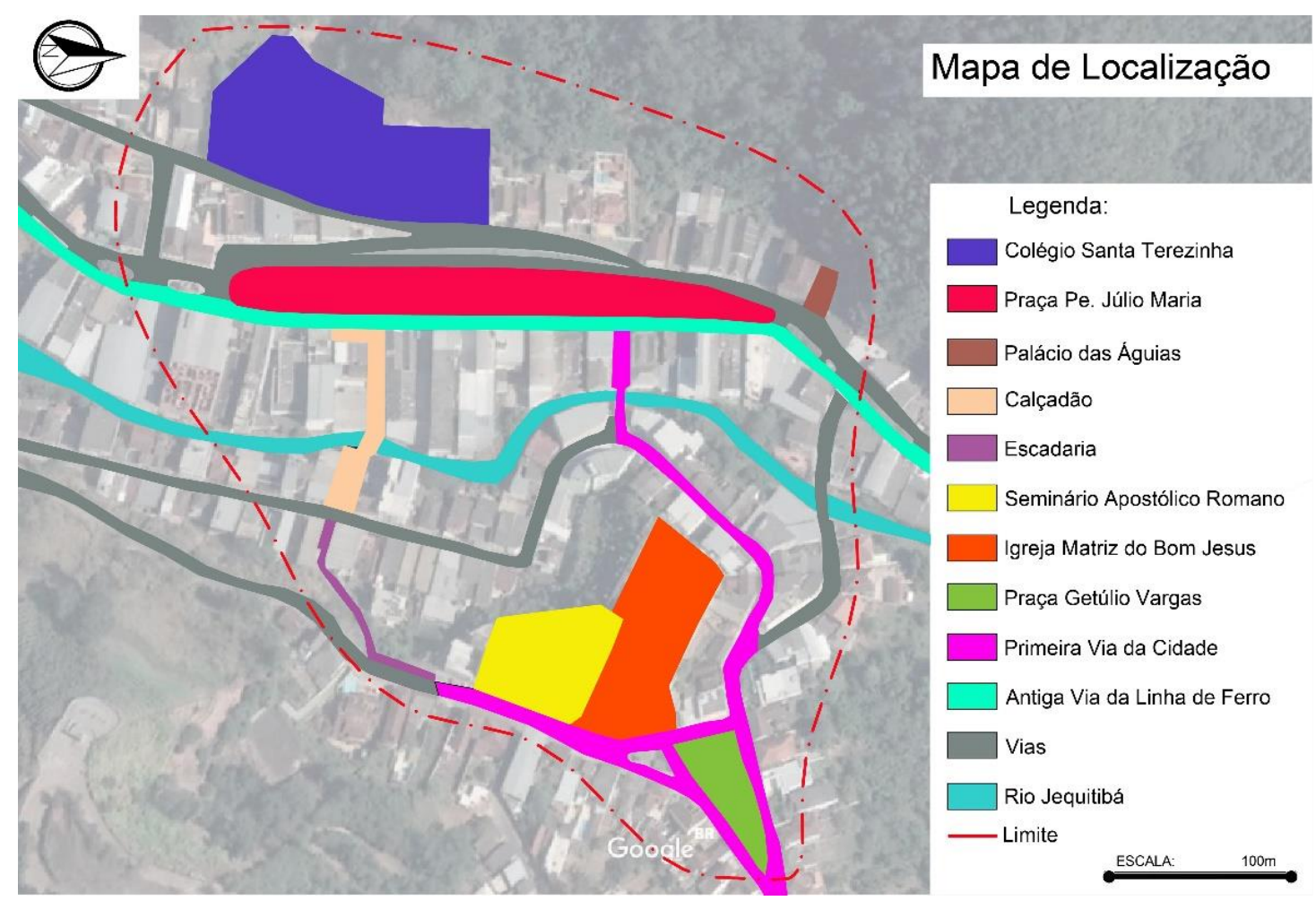


Fonte: Acervo das autoras, 2019

Como lembra Botelho (2011), a cidade cresceu graças a organização de produtores e trabalhadores rurais que fixaram moradia, principalmente por se tratar de um local fértil para a agricultura, vindo a ser considerado o primeiro centro da cidade marcado pelas vias de cor rosa no Mapa 1, principalmente depois da construção da Praça Central, atual Praça Getúlio Vargas, localizada na rua Padre Júlio Maria e demarcada no Mapa 1 na cor verde.

\subsubsection{A Praça Central - Getúlio Vargas}

De acordo com o historiador Botelho (2011), a Praça Central (Figura 6) foi criada por volta do ano de 1913 e servia como ponto de encontro da população, principalmente depois das celebrações religiosas na capela, que ficava localizada na área onde se encontra atualmente a Matriz da cidade. Atualmente, a praça se denomina Praça Getúlio Vargas (Figura 7) e é pouco utilizada devido a falta de infraestrutura de entretenimento atrativo a população.

Figura 6: Antiga Praça Central, 1920

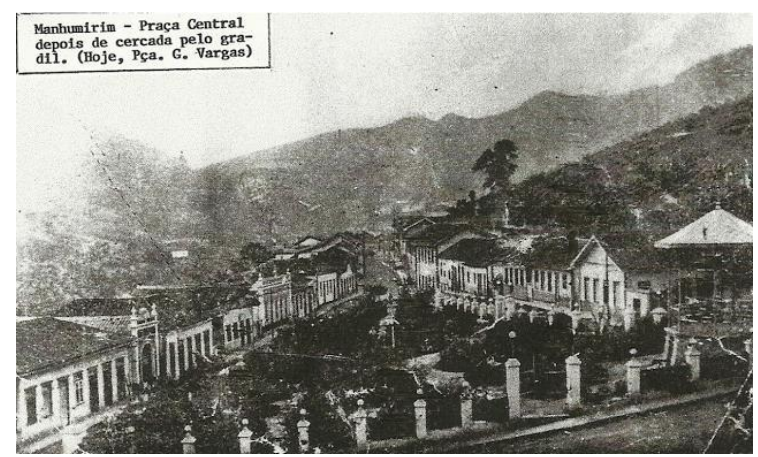

Fonte: Manhumirim, 2019
Figura 7: Praça Getúlio Vargas, 2019

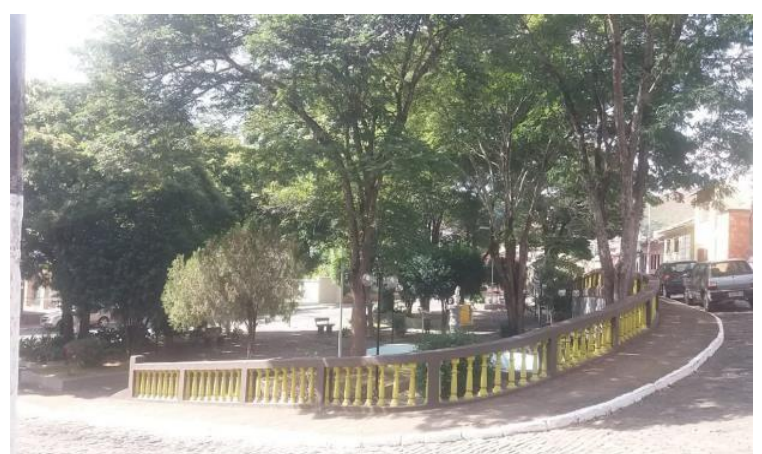

Fonte: Acervo das autoras, 2019

As imagens retratam o visível passar dos anos e a mudança estética ocorrida com o espaço no qual se originou o distrito. É importante salientar que cada uma das árvores retratadas na Figura 6 se tornaram as grandes árvores da Figura 7, evidenciando naturalmente o decorrer de aproximadamente um século de evolução urbana. Outra mudança estética visível se dá nas edificações, nas quais seu caráter histórico que carrega 
um estilo eclético mesclando o neoclássico e o art decó, vem se modificando pelo tempo, ganhando fachadas contemporâneas que, apesar de fazerem parte da evidente evolução urbana, fazem-se desalinhadas com a preservação histórica local.

Nota-se, nas imagens, também, os balaustres antigos, que antes delimitavam a praça, mas que, durante as modificações pelas quais o local passou, foram sendo substituídos por novos, o que antes eram pilares com topo piramidal foram modificados para novos balaustres mais curvilíneos e com menor espaçamento entre eles.

\subsubsection{Impulsos ao crescimento - A Ferrovia, a Emancipação e o Missionário}

Com o crescimento do interesse na fertilidade das terras, a cidade ganhou mais vias, casas e um novo ponto de interesse principal que se tornou o atual centro comercial da cidade. Segundo Botelho (2011), no ano de 1880, deu-se início à construção da estação ferroviária, que era o ponto de servidão da ferrovia que fazia ligação entre as cidades de Manhuaçu, cidade vizinha, também no estado de Minas Gerais até a cidade do Recreio dos Bandeirantes, no estado do Rio de Janeiro. A inauguração da ferrovia aconteceu no ano de 1915 (Figura 8) e reuniu a população manhumiriense que buscava o progresso.

Figura 8: Inauguração da Ferrovia, 1915

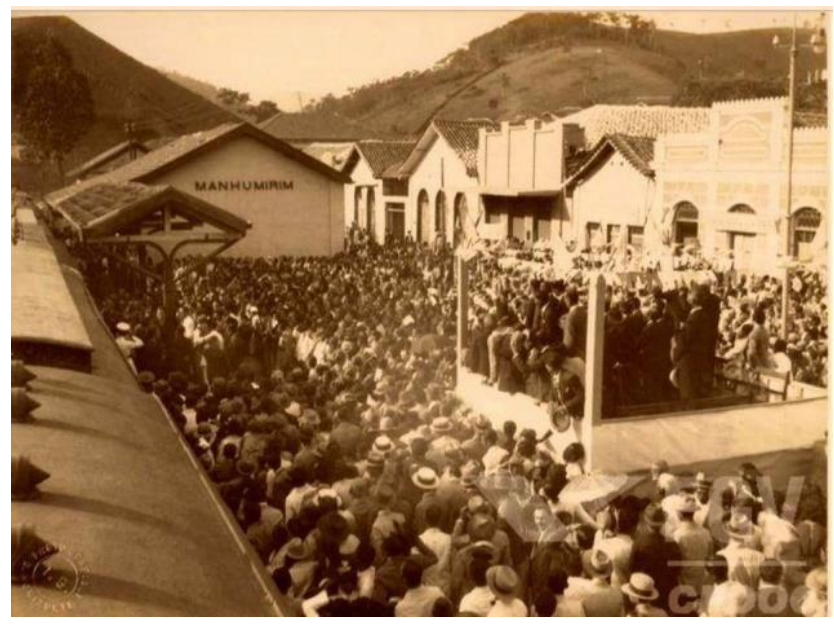

Fonte: Manhumirim, s/d. 
Ainda de acordo com Botelho (2011), a ferrovia era o meio mercantil mais eficiente e foi o meio de locomoção a longas distâncias que aumentava a circulação, principalmente na Zona da Mata Mineira. $\mathrm{O}$ trem fazia o trabalho diário de viagens que duravam cerca de doze horas vindo do Rio de Janeiro até Manhuaçu, levando cargas e passageiros. A linha de ferro, definitivamente, alimentou e fomentou o crescimento nas cidades na qual se fixou.

Outro impulso ao crescimento da cidade foi a emancipação do município que aconteceu no ano de 1924 e, a partir disso, o local tomou reconhecimento de cidade sede, possuindo assim outros distritos, como Durandé e Alto Jequitibá, que hoje são também emancipados (BOTELHO, 2011).

Ainda de acordo com Botelho (2011), o maior dos impulsos para o crescimento da cidade no âmbito histórico, social e cultural, aconteceu a partir do ano de 1928 com a chegada do missionário bélgico Pe. Júlio Maria de Lombaerde, o homem que, vindo de missões na Bélgica, África e Amazonas, fixou moradia em Manhumirim e influenciou o maior crescimento religioso e arquitetônico da cidade, apesar da resistência e perseguição por parte dos integrantes da maçonaria local. Com seus 95 anos de emancipação, Manhumirim possui uma história de longa data, que começou há mais de duzentos anos, o que a caracteriza fortemente como uma cidade com necessidade de preservação histórico-cultural.

\subsubsection{Praça da Estação}

A estação ferroviária em Manhumirim ficava localizada na antiga Praça da Estação (Figura 9) e ali esteve até o fechamento da estrada de ferro, no ano de 1975. Nesse mesmo ano, após o fim da utilização da ferrovia, ocorreu a demolição da estação; porém, ainda assim o centro da cidade possuía uma força comercial importante para o seu funcionamento, com isso, a praça ainda seguia como o centro de encontro da população e, atualmente, denomina-se Praça Padre Júlio Maria (Figura 10), em homenagem ao missionário precursor do crescimento da cidade. 
Figura 9: Antiga Praça da Estação, 1931

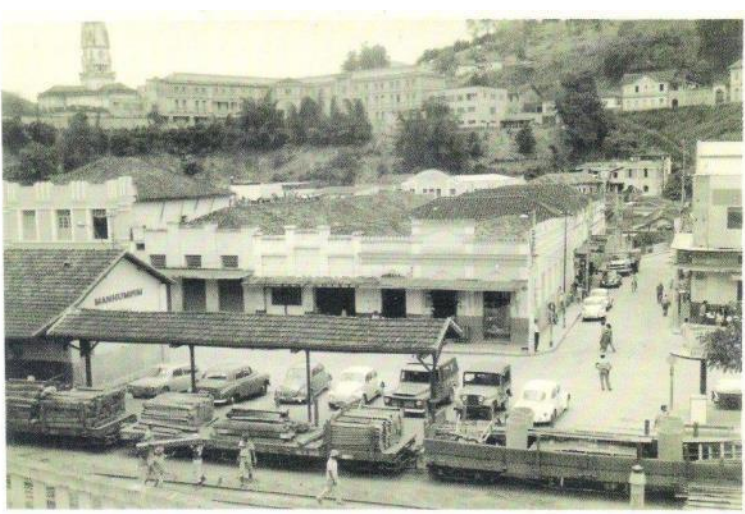

Fonte: Manhumirim, s/d.
Figura 10: Praça Padre Júlio Maria

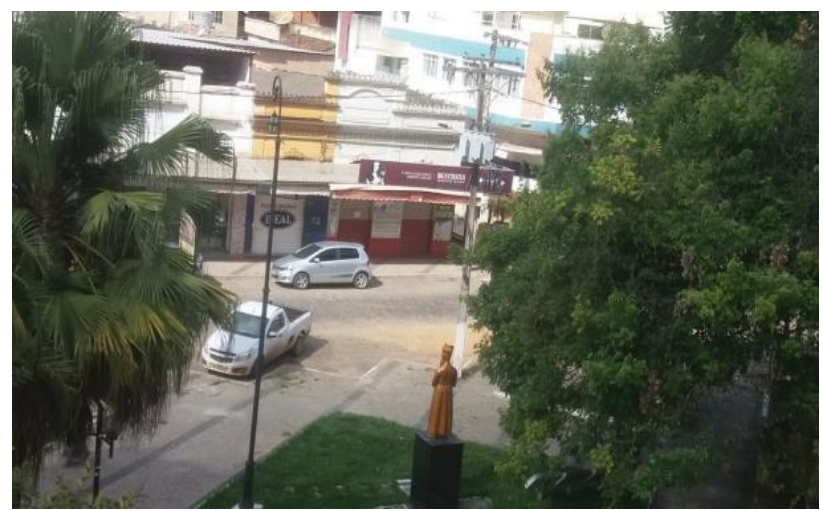

Fonte: Acervo das autoras, 2019.

Nota-se que, após o fim da utilização da estrada de ferro e com o centro permanecendo como o ponto de maior incidência comercial da cidade até os dias atuais, fizeram-se várias mudanças estéticas no local e no entorno. De uma área na qual se localizava o serviço mais importante da região, surgiu uma praça de contemplação, novas árvores foram inseridas em seus devidos canteiros. O local onde antes existia a edificação da estação abriga hoje uma estátua em memória do missionário predecessor do progresso da cidade.

A imagem dos dias atuais retrata o local no qual fica a estátua em homenagem ao pároco, local onde era a edificação da estação. Ao lado ficam os banheiros que foram construídos em uma das reformas e o local de feira que foi implementado no intuito de promover feiras orgânicas dos pequenos produtores da cidade, que expõem, uma vez por semana, seus produtos para serem comercializados, geralmente aos sábados no período diurno. Esse programa de incentivo ao comércio da agricultura familiar e orgânica é chamado de "Coisas da Terra" e gera movimento para o centro, onde funcionam os bancos, lojas e supermercados. Em contrapartida, parte da preservação local tem-se modificado junto às reformas. No ano de 2018, por obra da prefeitura, árvores centenárias foram cortadas, aumentando a insolação principalmente próxima ao playground, o que também descaracterizou a beleza natural e visual da praça nesse espaço em específico (Figura 11). 
Figura 11: Playground menos arborizado, 2019

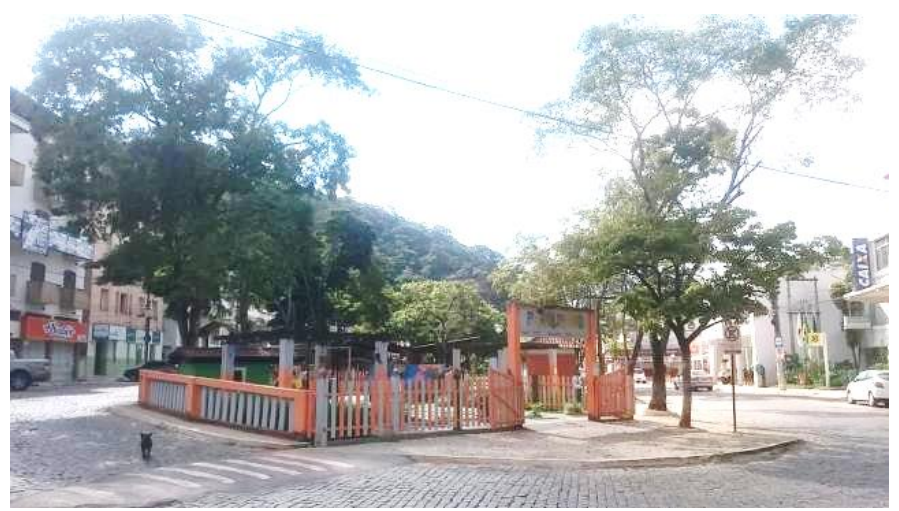

Fonte: Acervo das autoras, 2019

A praça, atualmente, conta alguns pontos específicos em seu uso, o referido playground, área das feiras, banheiros, coreto no qual acontecem eventos que, em sua maioria, são de caráter político e uma quadra para prática de peteca que ocupa o lugar do antigo chafariz, que era um ponto de contemplação muito bonito do local. No restante, há uma abundante arborização, pergolados de madeira com trepadeiras floridas, além de bancos de concreto, mobiliário urbano, tais como lixeiras, bancas de jornal e um pequeno comércio de sorvetes.

É válido ressaltar que a praça tem ligação com o "Calçadão" da cidade (Mapa 1), que é um largo muito utilizado para a travessia de pedestres entre ruas distintas e durante a noite, principalmente aos finais de semana, torna-se ponto de encontro para utilização de bares e restaurantes; contudo, a precariedade da preservação e dos atrativos no local o tornam ainda pouco utilizado. A administração da cidade, no ano de 2018, iniciou o cuidado dessas áreas, no entanto, não houve de fato uma melhora relevante, pois os espaços permanecem mau utilizados e com atratividade escassa.

Nos primórdios da cidade, não havia pavimentação, as ruas eram de terra batida e existiam apenas as divisões por meio-fio que as separavam das calçadas. Com o progresso, a pavimentação das ruas ficou a cargo de paralelepípedos assentados um ao lado do outro, permitindo escoamento natural de águas pluviais; no entanto, há pouca manutenção e é possível serem encontrados durante o percurso alguns desníveis que atrapalham a locomoção dos carros e dos pedestres (Figura 12). Já a pavimentação da praça (Figura 13) e do calçadão, é composta por pedras portuguesas que compõem desenhos geométricos simples que caracterizam a aparência de algo histórico, porém 
ainda superficial no âmbito da preservação da cultura local, o que deveria ocorrer, por se tratar de uma cidade quase centenária com muita história pra contar.

Figura 12: Pavimentação com baixa manutenção, 2019

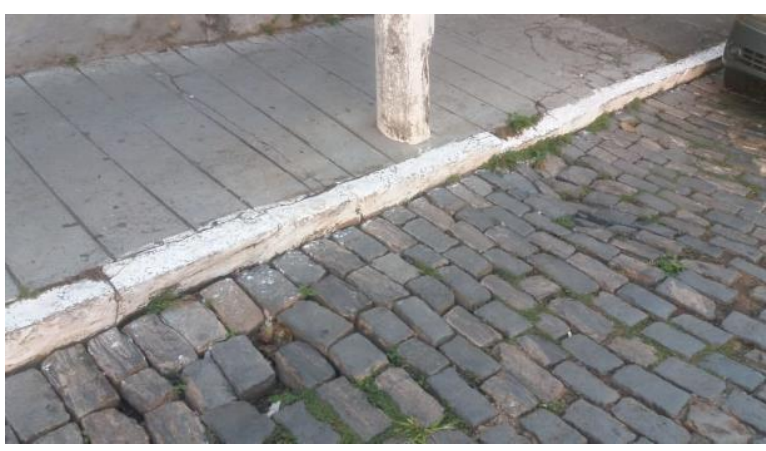

Fonte: Acervo das autoras, 2019
Figura 13: Paginação de piso da atual Praça Pe. Júlio Maria, 2019

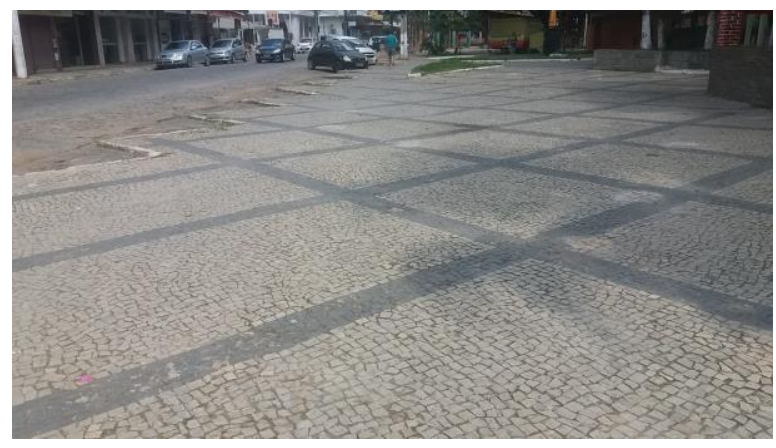

Fonte: Acervo das autoras, 2019

\subsubsection{O Palácio das Águias}

Datando da mesma época, por volta de 1924, e localizado ao lado da Praça Pe. Júlio Maria, o Palácio das Águias leva esse nome por possuir no alto de sua fachada esculturas de águias brancas. De acordo com Manhumirim (2006), a edificação foi construída especificamente para uso comercial, operava em seu térreo um armazém de café e, no pavimento superior, a Agência do Banco Mineiro do Café. O banco, por sua vez, foi a segunda casa bancária de Manhumirim, precedida somente pelo Banco de Crédito Real de Minas Gerais. Após o fechamento da agência do Banco Mineiro do Café, a parte superior do prédio passou alguns anos inutilizada e seu térreo, antes utilizado para o fim de armazém de café, passou a ser o Supermercado Minarrini, que, com o passar dos anos, mudou-se para outro local ainda no centro da cidade. Posteriormente, o térreo foi utilizado para diversos fins comerciais, como lojas de roupas, móveis, entre outros.

Ainda de acordo com Manhumirim (2006), a edificação é uma propriedade privada, agora de uso misto e pertence a família Cotrim, que hoje reside no local. Constituída de dois pavimentos, o térreo ainda é utilizado como ponto comercial e o primeiro andar é constituído por dois apartamentos, sendo um voltado para a fachada da rua e o outro para a fachada posterior do edifício. 
Em relação ao estilo arquitetônico, a obra possui tipologia eclética, devido ao processo de reformas ao longo dos anos, mas prevalecendo o estilo Neoclássico (Figura 14), enquanto as edificações atualmente construídas ao redor não possuem estilo definido, uma vez que a maior parte dos prédios antigos originais do local foram demolidos para dar lugar a novos edifícios mais modernos, devido a ocupação urbana mais recente, podendo ser caracterizada como típica da arquitetura popular brasileira. Há também o adensamento das construções, visando o maior aproveitamento dos terrenos, visto que se localiza em um dos pontos mais valorizados no município, contribuindo para a criação de uma vizinhança predial, gerando materialidades e volumetrias distintas, concorrendo visualmente com o Palácio das Águias (Figura 15), dando ao mesmo um destaque ímpar no meio urbano.

Figura 14: Fachada revitalizada e modificada no térreo



Fonte: Acervo das autoras, 2019
Figura 15: Relação da fachada com as outras edificações

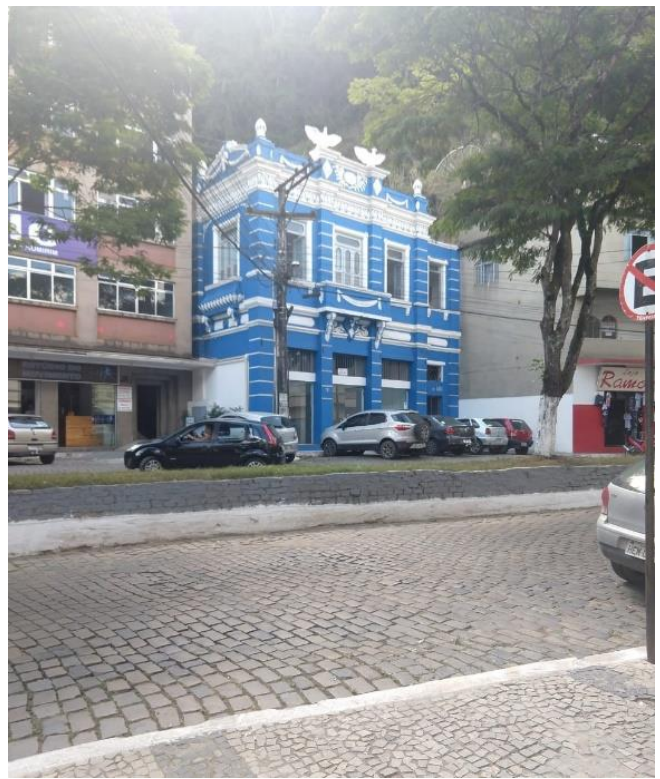

Fonte: Acervo das autoras, 2019

Pode-se observar nos detalhes que constituem suas principais características quanto ao estilo arquitetônico que, apesar de ser eclético, devido as reformas ao longo dos anos, destacam-se características do neoclassicismo e do barroco, em alta nos séculos XVIII e XIX. Com relação ao estilo neoclassicista, pode-se mencionar as características que estão em evidência no edifício, como o uso da simetria, linhas 
ortogonais, formas geométricas regulares e simétricas, volumes corpóreos e maciços e utilização de colunas como elemento estético. Em complemento, no que se refere ao estilo barroco, pode-se destacar a utilização de colunas como suporte e decoração, elementos decorativos variados e exuberantes, misto da pintura e escultura, uso de elementos tipicamente incomuns e extravagantes.

O prédio encontra-se na cor azul escuro com detalhes em branco, incluindo as esculturas. As esquadrias em madeira no primeiro andar estão pintadas na cor original com um tom azul acizentado, enquanto as portas do pavimento térreo foram trocadas por versões em vidro com o intuito de valorizar o ponto comercial, o portão que dá acesso a circulação vertical do prédio permanece em ferro.

\subsubsection{A Igreja Matriz do Senhor Bom Jesus}

A primeira obra construída por intermédio do missionário Padre Júlio Maria de Lombaerde foi a Igreja Matriz do Bom Jesus, localizada no terreno cedido pelo primeiro desbravador da cidade, o já citado Manoel Francisco. Segundo Botelho (2011), a igreja é a primeira construção desse porte e dessa tipologia feita inteiramente em concreto armado de toda a América Latina, suas paredes internas possuem pinturas originais da primeira construção, que retratam passagens da Bíblia e cultuam o catolicismo. O fím de sua construção data de 1930 e, com um estilo gótico, a igreja é um patrimônio religioso de grande importância também para a revolução da construção civil (Figuras 16 e 17).

Figura 16:Igreja Matriz em construção, 1928



Fonte: Rosendo, 2010
Figura 17: Fachada da Igreja

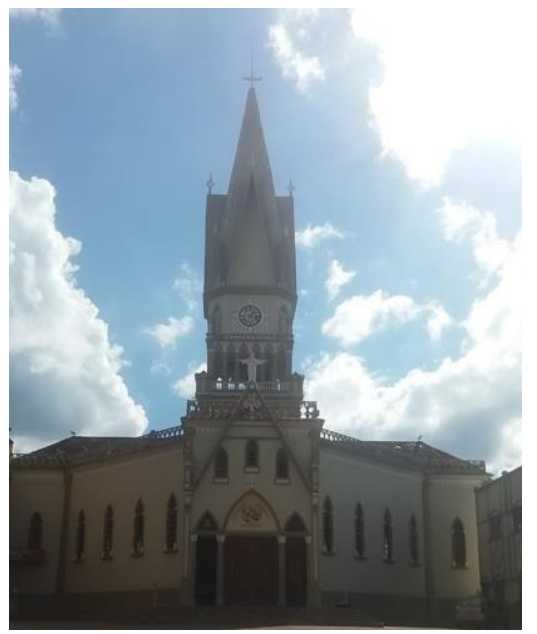

Fonte: Acervo das autoras, 2019 
A igreja permanece, de acordo com Botelho (2011), com grandes janelas de arcos ogivais e uma torre pontiaguda que se destaca na fachada como elemento principal. $\mathrm{O}$ interior da edificação conta com abóbadas e arcos ogivais, bem como a estrutura arcobotante que suporta de modo esteticamente belo a estrutura em concreto armado. As pinturas possuem cores vivas e sua planta possui o formato de cruz latina, característico do estilo. Botelho (2011) defende que o estilo arquitetônico é o gótico; contudo, analisando todas as características mencionadas, entende-se que se trata do estilo neogótico.

Ainda de acordo com Botelho (2011), a igreja é palco de um evento social que movimenta a cidade uma vez por ano, entre os dias sete e quatorze do mês de setembro, em que ocorre o Jubileu do Bom Jesus, uma festa histórica da cidade, que data de 1917, e, mesmo cem anos depois de sua promoção, continua mobilizando inúmeros fiéis de diferentes partes do país que, com o intuito de homenagear o Senhor Bom Jesus, padroeiro dessas terras, deslocam-se até a cidade no período da festa para celebrar sua fé. Por isso, em algumas vezes, a igreja passou por reformas e restauração; a última aconteceu por volta do ano de 2015 e contou com a experiência do restaurador Otoniél Paschoal de Souza e uma equipe de artistas locais.

De acordo com Manhumirim (2006), o local da igreja se trata de um bem municipal inventariado no ano de 2006, visando um possível tombamento para se tornar um patrimônio municipal e nacional, frente a toda sua carga histórica e sua importância, não somente para a cidade, mas também para a todo o Brasil, considerando, principalmente, sua importância na história da construção civil com base em sua arquitetura e estrutura.

Nos anexos da igreja, tem-se o salão paroquial, responsável por comercializar itens relacionados a religiosidade, a gráfica e a editora "O Lutador", que tem grande importância na publicação e disseminação de conteúdo religioso, fundada também por Padre Júlio Maria, que, em seus anos de missão nessas terras, criou o jornal diário e semanal da cidade e escreveu e publicou suas obras (BOTELHO,2011).

\subsubsection{Seminário Apostólico Romano e Colégio Pio XI}


Outra área independente, porém que oferece suporte ao Santuário, é o Seminário Apostólico Romano (Figura 18), obra do pároco, que, desde sua concepção, serve de abrigo a ordem Sacramentina da cidade, os denominados "filhos de Júlio Maria". Segundo Botelho (2011), o seminário abriga os alojamentos paroquiais destinados aos seminaristas e sacerdotes, e o Ginásio Pio XI, que se tratava de uma escola de filosofia e teologia para os futuros padres, foi uma obra que se estendeu por nove anos, começando no ano de 1931 e sendo finalizada em sua totalidade em 1940. Por serem "vizinhos", a relação visual entre a igreja e o seminário (Figura 19) é uma batalha entre gigantes que esteticamente acaba por ser uma experiência harmônica e definitivamente única.

Figura 18: Fachada Perspectiva do Seminário,Figura 19: Relação visual entre as

2019

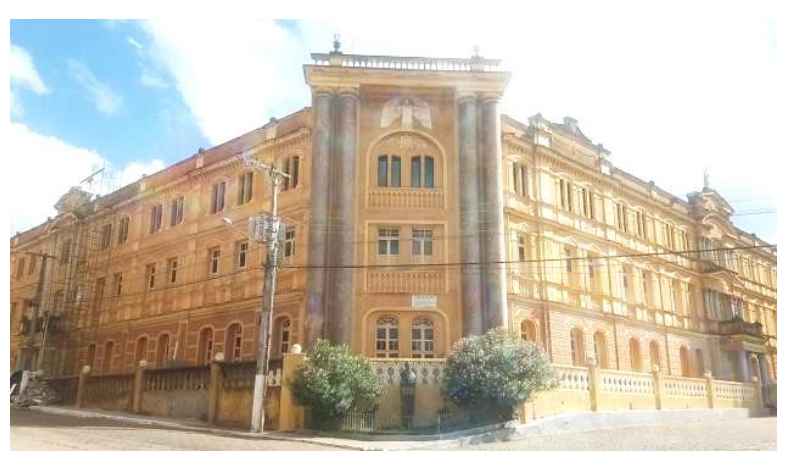

Fonte: Acervo das autoras, 2019 edificações, 2019



Fonte: Acervo das autoras, 2019

A imponência das colunas nas entradas da edificação e na lateral remetem a arquitetura clássica; no entanto, pode-se considerar uma arquitetura eclética, como o restante das obras dessa mesma época. A ideia do ecletismo se concretiza a partir da mudança dos formatos de janelas, que ora têm acabamentos arqueados e ora retilíneos; por se tratar de uma obra de grande porte que gerava grandes custos, o Seminário foi construído por partes, como conta Botelho (2011), e isso pode ter sido o motivo para que não houvesse um padrão no modo construtivo. As cores da edificação permanecem originais, mantendo a caracterização histórica. Sua utilização já passou por mudanças, funcionando como colégio comum a crianças e a adolescentes por volta de vinte anos atrás. 
As duas edificações, a igreja e o seminário, conversam visualmente, às vezes parecem competir em imponência e outras vezes parecem combinar perfeitamente. É necessário compreender que as duas edificações formam juntas um núcleo de grande importância religiosa e social para a cidade, um conjunto arquitetônico que deve ser preservado de maneira adequada e que, de modo diluído, vem sendo restaurado.

Confirmando Lynch (1997), nota-se que a paisagem formada pelos elementos históricos de uma cidade, quando carregada de significado e memória, torna o meio em que estão inseridas mais atrativo e agradável. É válido ressaltar que a beleza resultante da história das edificações carrega consigo a formação da imagem da cidade.

\subsubsection{O Colégio Santa Teresinha}

A terceira edificação de grande importância na obra do sacerdote Padre Júlio Maria de Lombaerde é o Colégio Santa Teresinha, também conhecido como Escola Normal que, segundo Botelho (2011), especula-se ter sido construído quase que se equiparando a data da construção do Seminário; no entanto, nessa obra em particular, o sacerdote contou com a ajuda administrativa de uma mulher importante para a história da edificação, Madre Beatriz, que incentivou não somente a construção do colégio de freiras, mas também o crescimento acadêmico da região.

Os interesses da Madre Beatriz, juntamente com os de Padre Júlio Maria, eram de que a cidade se tornasse um polo não somente no âmbito da educação religiosa, mas também no que compete a educação acadêmica. Por esse motivo, cursos que agregassem no pensamento do cidadão começaram a ser propostos. No ano de 1944, já funcionava nas instalações da Escola Normal o Conservatório de Música de Manhumirim que atendia a cidade e a região. A partir disso, foi incentivada a abertura também das faculdades de letras, filosofia e ciências, utilizando das instalações do então Colégio Santa Teresinha (Figuras 20 e 21). Entretanto, por mais que os sacerdotes, as irmãs e o povo ansiassem pela implementação dessas faculdades, não era de interesse político que a ideia tomasse força e, por esse motivo, o projeto acabou deixado de lado no ano de 1983, fazendo assim com que a busca pela utilização do colégio diminuísse, causando o seu fechamento (BOTELHO, 2011). 
Figura 20: C. Santa Teresinha, s/d

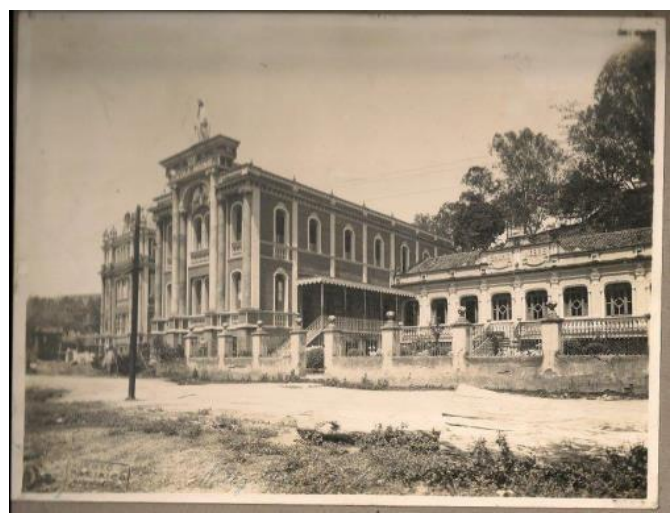

Fonte: Manhumirim, s/d
Figura 21: Colégio Santa Teresinha, 2019



Fonte: Acervo das autoras, 2019

Por se tratar de uma obra de mesma época que o Seminário, possui também as mesmas características clássicas, com um detalhe especial nas colunas da fachada que possuem capitel jônico e que trazem uma característica diferenciada das colunas da outra edificação. A escola permaneceu com parte das edificações originais, no entanto, por motivos de deterioração temporal, algumas partes foram modificadas (Figura 22), evidenciando a clara mudança temporal ocorrida com as décadas seguintes.

Figura 22: Colégio Santa Teresinha, 2013

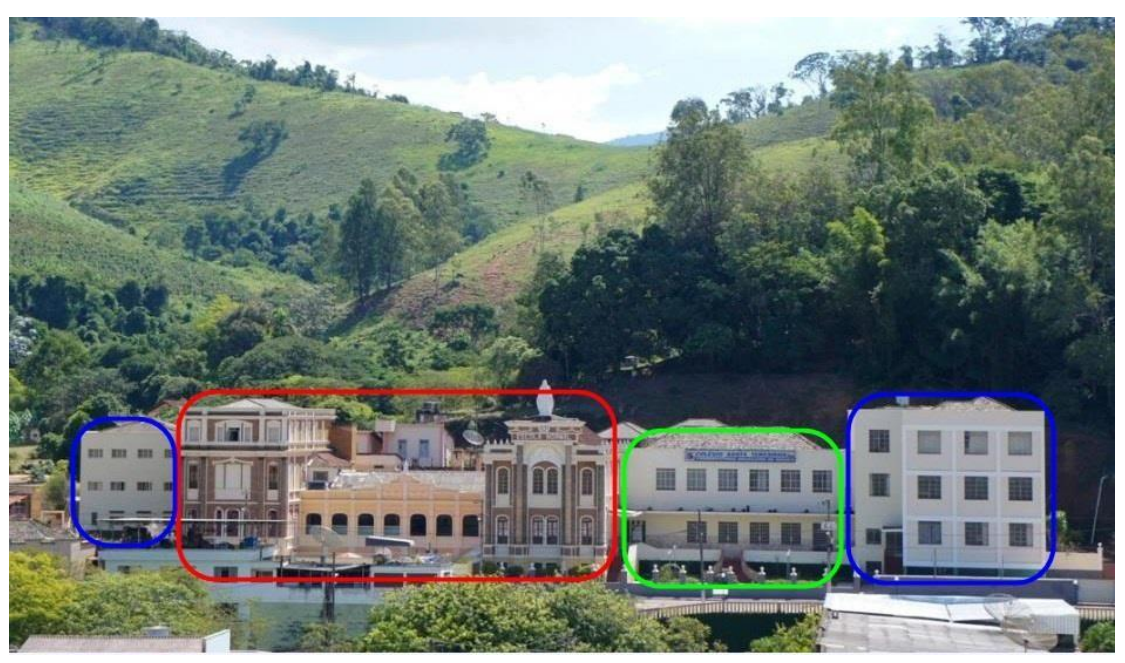

Fonte: Adriano, 2013 (editado pelas autoras)

Nota-se, então, que hoje o colégio possui seis blocos interligados, os blocos em marrom e laranja (destacados por vermelho) são originais, o bloco onde se encontra a placa do colégio (marcado em verde) possui dois andares diferentemente do original que 
possuía apenas um pavimento e os outros dois blocos (em azul), de três andares, foram anexos construídos para comportar o novo uso, que, segundo Botelho (2011), deu-se por volta de 1990, quando outra irmã foi convidada a ser a nova diretora, uma vez que Madre Beatriz já tinha uma idade bastante avançada. Desde então, o colégio se tornou uma instituição de ensino particular, desde os primeiros anos da infância até o final do ensino médio, chegou também a abrigar cursos de pedagogia, geografia e história, mas, por ter ganhado uma competição direta com as instituições que cresciam em cidades como Carangola, Caratinga e Manhuaçu, a busca pelo ensino superior não gerava dinheiro nem mesmo para cobrir os gastos e, com isso, a faculdade que ainda tentava buscar espaço, foi fechada novamente.

\subsubsection{Das competências legislativas e sua importância urbana e patrimonial}

Das edificações citadas que permeiam o centro histórico de Manhumirim, o colégio é a que possui mais mudanças em sua arquitetura original, entretanto, no que lhe resta dos primórdios de sua construção, a conservação permanence exemplar, visto que sofreu uma reforma recentemente para melhoria das fachadas e, com isso, ganhou mais vida. $\mathrm{O}$ seminário passa por constantes reformas, mas vários fatores podem ser apontados para a alta incidência de necessidade de manutenção. Sua grandiosidade, a ação do tempo, falta de mão de obra qualificada e investimento insuficiente para mantê-lo podem ser os principais motivos.

De acordo com Stephan (2017), os municípios menores localizados na Zona da Mata Mineira possuem dificuldade de adaptação e implementação de políticas públicas urbanas, dado o notório desânimo frente a administração da grande maioria dessas cidades, que, muitas vezes, possuem planos de desenvolvimento urbano por obrigação ou pressão judicial; sem esses dois motivos, acredita-se que haveria ainda mais descaso com a efetividade de um planejamento de qualidade.

No que se refere a essas políticas públicas, a legislação da cidade é precária e obsoleta. De acordo com Manhumirim (2006), a cidade possui um plano denominado Lei Orgânica, um único arquivo que engloba todas as leis do município no que tange o crescimento e a administração econômica e territorial da cidade, não possuindo então um Plano Diretor Urbano, apesar da exigência do Estatuto da Cidade, que, segundo Brasil 
(2001), exige que os municípios acima de vinte mil habitantes que não tivessem um Plano Diretor Urbano, teriam então cinco anos para se adequar mediante a data de promulgação do estatuto.

Esse arquivo legislativo data de 2006 e desde então não passou por nenhuma mudança ou revisão, além disso, é o único arquivo disponibilizado ou que se tem fácil acesso. Contudo, a falta de diretrizes de fato aplicadas tem feito com que exista uma notável falta de infraestrutura urbana, o que afeta diretamente o patrimônio existente, principalmente no centro histórico, uma vez que a circulação no local é maior que no restante da cidade.

De acordo Manhumirim (2006), é de competência do município, segundo o capítulo II, Art. 13, parágrafos III a VII, a preservação e salvaguarda de quaisquer monumentos históricos, patrimônios naturais e movimentos culturais, proporcionando meios necessários de acesso da cultura, educação e ciência. No entanto, durante a pesquisa, foi possível notar que esse acesso, muitas vezes, é dificultado pela administração. $\mathrm{O}$ acesso à legislação é escasso e não são disponibilizadas informações básicas referentes a novas propostas de diretrizes, também não são concedidas respostas a questionamentos simples no que compete então a aplicação das leis existentes. Elas são generalizadas, não possuindo caráter específico, uma vez que é sempre lembrado que serão seguidas as leis federais durante todos os capítulos do único documento disponível para acesso.

Uma vez que o município possui legislação - mesmo que escassa - que se refere a preservação, pode-se confirmar o que afirma Canani (2005), que é de total responsabilidade do poder administrativo da cidade e dos usuários a preservação dos patrimônios existentes. Entretanto, ainda fica claro que a cidade necessita de diretrizes que sejam propostas e aplicadas, não somente no que compete a administração, mas também ao usuário, uma vez que o caráter histórico da região, aliado a leis que sejam efetivas, não somente agregariam um potencial turístico rico no centro da cidade, mas aumentariam o fluxo econômico do local. Além disso, validando o que argumenta Lynch (1997), uma cidade precisa de sua memória que é construída pelo tempo e a imagem da cidade no contexto geral é a interação desses elementos: memória, funcionalidade, preservação e paisagem. 
Confirmando as alegações de Gomes (2011), o patrimônio histórico e a cultura são pontos importantes da cidade, as edificações configuram o espaço misturando a história com a contemporaneidad e é, por esse motivo, que é tão importante que haja a associação de políticas públicas que se correlacionem buscando a melhora do espaço urbano como elemento de ligação entre patrimônios ou mesmo como o próprio patrimônio.

\section{CONCLUSÃO}

Com base no que foi apresentado, entende-se que a preservação patrimonial é de suma importância para o contexto geral da cidade, pois é ela quem cria a paisagem cultural do local e remete a memória do usuário, que, por sua vez, é também o grande responsável pelo resgate sociocultural do espaço urbano. Todavia, a memória, a cultura e o patrimônio devem ser amparados por leis que os salvaguardem e administrações que apliquem as diretrizes ideais.

A cidade de Manhumirim é berço de obras de grande valor histórico e religioso. A história da cidade data de muito tempo atrás e suas obras locadas no centro histórico carregam um valor imensurável para a população local. No entanto, a preservação ainda é escassa e se fazem importantes diretrizes urbanas e de preservação patrimonial que, se devidamente aplicadas, poderiam gerar mais turismo, melhorando assim a economia local.

A carência de leis que competem à área urbana e à patrimonial acarreta na modificação da paisagem de forma desordenada e algumas mudanças, muitas vezes, não agregam no patrimônio existente. Contudo, o progresso não é algo a ser desencorajado, deve-se haver o desenvolvimento da cidade, desde que esse respeite a memória e o patrimônio. Aliando preservação e evolução, é possível transformar o meio urbano em um local de experiências únicas.

\section{REFERÊNCIAS}

ACIAMA, Associação Comercial, Industrial e Agropecuária de Manhumirim. História de Manhumirim. Manhumirim: ACIAMA, s/d. Disponível em: < http://www.aciama.com.br/site/index.php?option=com_content $\&$ view $=$ article $\&$ id $=86 \%$ 3A2015-06-11-14-03-02\&catid=8\%3Adestaques\&Itemid=1>. Acesso em: 05 mai. 2019. 
ADRIANO. Institucional. Galeria de fotos. Minas Gerais: Manhumirim, 2013. Acesso em: < https://www.manhumirim.mg.leg.br/institucional/fotos/dsc01185.jpg/view> Acesso em 20 mar. 2019

ALBERTI, V. Ouvir Contar: Textos em História Oral. Rio de Janeiro: FGV, 2004

BARRETO, A. M. Direito à cidade na cidade espetáculo: simulacros e utopias. 2008. Dissertação (Mestrado em Direito) - Faculdade de Direito, Universidade de Brasília, Brasília, 2008. p. 135-141.

BOTELHO, Pe.D.A. História de Manhumirim: Município e Paróquia. Manhumirim: O Lutador, 2011.

BRASIL. Constituição da República Federativa do Brasil (1988). Promulgada em 05 de outubro de 1988. Disponível em: < http://www.planalto.gov.br/ccivil_03/Constituicao/Constituicao.htm> Acesso em: 21 mar. 2019.

BRASIL. Estatuto da Cidade. Promulgada em 10 de junho de 2001. Disponível em: < https://presrepublica.jusbrasil.com.br/legislacao/101340/estatuto-da-cidade-lei-1025701> Acesso em: 02 jun. 2019.

BUCCI, M. P. D. Fundamentos para uma teoria júridica para as políticas públicas. São Paulo: Saraiva, 2013.

CAMPOS, H.R. Gentrificação na área central de Tiradentes/MG. Mercator, v.12, n.29, 74-78, set-dez, 2013.

CANANI, A.S.K.B. Herança, sacralidade e poder: sobre as diferentes categorias do patrimônio histórico e cultural no Brasil. Horizontes Antropológicos, v.11, n.23, s/p, 2005. Disponível em: < http://www.scielo.br/scielo.php?pid=S0104-

71832005000100009\&script=sci_arttext $>$. Acesso em: 16 mar. 2019

CASTRO, C.Y. A Importância da Educação Patrimonial para o Desenvolvimento do Turismo Cultural. 2006. Dissertação (Mestrado em História) - Departamento de História, Universidade de Caxias do Sul, Caxias do Sul, 2006.

DÉBORA, Papetes pelo mundo. Bate e Volta: Paraty (RJ). Paraty: Débora, 2015. Disponível em:< https://papetespelomundo.com/2015/06/23/bate-volta-paraty-rj/>. Acesso em: 02 mar. 2019.

DEL RIO, V.; SIEMBIEDA, W. Desenho urbano contemporâneo no Brasil. Rio de Janeiro: LTC, 2013.

FUNARI, P.P.; PELEGRINI, S.C.A. Patrimônio Histórico e Cultural. Rio de Janeiro: Zahar, 2009. 
GOMES, M.A.A.F. Preservação e Urbanismo: encontros, desencontros e muitos desafios. In: GOMES, M.A.A.F.; CORRÊA, E.L. Reconceituações contemporâneas do Patrimônio. Salvador: EDUFBA, 2011.

GURI ESTRADEIRO, Relatar, mostrar e discutir minhas experiências de pequenas viagens. PARATY-RJ-Brasil. Paraty: 2015. Disponível em:<

http://guriestradeiro.blogspot.com/2015/01/paraty-rj-brasil-em-breve.html>. Acesso em: 02 mar. 2019.

HORTA, M.L.P.; et al. Guia básico da educação patrimonial. São Paulo: IPHAN, 1999.

IPHAN, Instituto do Patrimônio Histórico e Artístico Nacional. Educação Patrimonial. Brasilia: Iphan, 2014. Disponível em:< http://portal.iphan.gov.br/pagina/detalhes/343>. Acesso em: 21 mar. 2019.

IPHAN, Instituto do Patrimônio Histórico e Artístico Nacional. Patrimônio Material. Brasilia: Iphan, 2014. Disponível em:< http://portal.iphan.gov.br/pagina/detalhes/276>. Acesso em: 21 mar. 2019.

IBGE, Instituto Brasileiro de Geografia e Estatísticas. Cidades: Manhumirim. Brasília: IBGE, 2017. Disponível em:< https://cidades.ibge.gov.br/brasil/mg/manhumirim/panorama>. Acesso em: 02 mai. 2019.

JARDIM, J.M. A invenção da memória nos arquivos públicos. Ciência da Informação, v.25, n.02, 1995.

LE GOFF, J. História e memória. Campinas: Unicamp, 1990.

LEMOS, C.A.C.. O que é patrimônio histórico. São Paulo: brasiliense, 2017.

LYNCH, K. A imagem da cidade. São Paulo: Martins Fontes, 1997.

MANHUMIRIM, Prefeitura Municipal. Arquivo de bens inventariados. Minas Gerais: Manhumirim, 2006.

MANHUMIRIM, Prefeitura Municipal. Acervo de fotografias. Minas Gerais: Manhumirim, s/d.

MULOCK, B. Cronologia do Pensamento Urbanístico, Acervo de Imagens. Bahia: Salvador, s/d. Disponível em:

<http://www.cronologiadourbanismo.ufba.br/apresentacao.php?idVerbete=1592> Acesso em: 05 abr. 2019

ORIÁ, R. Memória e ensino de História. In: BITTENCOURT, Circe(org). O Saber histórico na sala de aula. 10. ed. São Paulo: Contexto, 2013. 
PARATY. Prefeitura Municipal de Paraty/RJ. Centro Histórico. Disponível em: < http://www.paraty.com.br/centro_historico.asp> Acesso em: 05 abr. 2019.

PARATY. Prefeitura Municipal de Paraty/RJ. Caminho do Ouro. Disponível em: < http://www.paraty.com.br/caminho.asp> Acesso em: 05 abr. 2019.

PELEGRINI, S.C.A. Cultura e natureza: os desafios das práticas preservacionistas na esfera do patrimônio cultural e ambiental. Brasil Histórico, v.26, n.51, s/p, 2006.

Disponível em: < http://www.scielo.br/scielo.php?pid=S0102-

01882006000100007\&script=sci_arttext $>$. Acesso em: 11 mar. 2019

PEREIRA, F. C. Arquivos, memória e justiça: Gestão documental e preservação de acervos judiciais no Rio Grande do Sul. Disponível em:

<http://www.lume.ufrgs.br/handle/10183/31152>. Acesso em: 12 mar. 2018

REIS, N.G. Patrimônio Cultural e problemas urbanos. In: GOMES, M.A.A.F.; CORREA,

E.L. Reconceituações contemporâneas do Patrimonio. Salvador: EDUFBA, 2011.

ROCHA, T.S.F. Refletindo sobre memória, identidade e patrimônio: as contribuições do programa de Educação Patrimonial do MAEA-UFJF. In: XVIII Encontro Regional, 2012, Minas Gerais. Anais... Mariana: AMPUH-MG, 2012.

ROSENDO, J. A história do Jubileu do Bom Jesus. Minas Gerais: Manhumirim, s/d. Disponível em: < http://jornalbocadopovo.com/noticia_historia-do-jubileu-do-bomjesus-de-manhumirim-cem-anos-de-fe-na-cruz-de-cristo.html> Acesso em: 22 mar. 2019

SIMMEL, G. Limitação das cidades pequenas. In: CHOAY, F. O urbanismo: Utopias e realidades, uma antologia. São Paulo: Perspectiva, 2013.

STEPHAN, I.I.C. Entre a Obrigação e a Implantação de Planos: As Dificuldades de Planejar em Municípios da Zona da Mata Mineira. Viçosa: UFV, 2017.

TOMAZ, P.C. A Preservação do Patrimônio Cultural e sua Trajetória no Brasil. Revista de História e Estudos Culturais, v.2, n.2, p.2-12, mai-ago, 2010.

VARELA, A. Informações Pelourinho, 2015. Disponível em: <http://www.acheiviagem.com.br/pelourinho-em-salvador/62/atracao.html> Acesso em: 05 abr. 2019 